\title{
Evidence on the Financial Capability of Older Workers Facing Lump-Sum Retirement Plan Distributions
}

\author{
Jason S. Seligman \\ John Glenn School of Public Affairs \\ The Ohio State University, USA \\ E-mail: seligman.10@osu.edu
}

Received: August 28, 2012

Accepted: September 25, 2012

Online Published: October 31, 2012

doi:10.5430/afr.v1n2p177

URL: http://dx.doi.org/10.5430/afr.v1n2p177

This research was supported by a grant to Jason S. Seligman by funder who wishes to remain anonymous.

\begin{abstract}
Author Note
Two Appendices to this paper are available from the author at any time by request. The first, details financial literacy components of the survey instrument fielded as part of this work. The second documents differences in this survey instrument from others that have been fielded.
\end{abstract}

\begin{abstract}
Late career workers with lump-sum retirement plans face important financial decisions. Because ability and confidence interact when making financial decisions, this paper asks two related questions: Are workers approaching retirement financially capable of making decisions regarding lump-sum retirement benefits? Do they see themselves as capable? Comparing self-assessed measures of financial capacity to more objective measures reveals patterns of under and overconfidence in financial matters by socio-economic group. Comparing questions correlation to overall score, compound interest concepts are found to be strongly correlated with overall financial literacy. Findings suggest that financial planners may act as partial compensation for a lack of financial literacy, especially among the wealthy. This papers findings support: (1) developing tools that help potential clients engage and assess the work of financial managers, (2) including both self-assessment and objective finance questions on planners' client intake surveys and (3) facilitating client understanding of compound interest concepts.
\end{abstract}

Keywords: Financial well-being, Retirement planning, Lump-sum distributions, Financial literacy, Financial capability, Financial education

\section{Introduction}

At retirement, defined contribution plans typically pay out lump-sums by default, shifting post-retirement allocation and longevity risks to individuals. Many traditional defined benefit pension plans now also allow for some or all of the accrued pension value to be taken as a single lump-sum payment at the participant's discretion. Thus those in either type of retirement plan are increasingly required to make financial decisions about fund distributions as they retire. Two separately necessary but perhaps alone insufficient conditions for competent stewardship are capability and confidence. This paper thus centers on two related queries:

-1- Are workers approaching retirement financially capable of making decisions regarding lump-sums?

-2- Do they see themselves as capable?

To address these questions the paper analyzes retirement readiness and financial literacy for a sample of elder workers, all of whom are poised to make decisions regarding the distribution of lump-sums from an employer plan. Worker vulnerabilities are found in terms of both capacity and perceived capacity to make necessary financial decisions. The paper focuses on patterns of financial vulnerability and the implications of those patterns for practice and policy. The distinguishing contribution of this article is its focus on a group of elder workers who have a strong incentive to learn how to manage a lump-sum distribution so as to best provide for their retirement. All of persons in these data face a lump-sum payout decision in the near-future. 
Herein non-white minorities, women and those in the top decile of the wealth distribution all display vulnerability in terms of financial decision making capacity. Females and minorities present as having less financial literacy than white males. Regarding perceived capacity, women are found to display a further mild relative under-confidence, while minority and high wealth groups display strong overconfidence relative to white males in the sample. Those reporting the highest wealth evidence low financially literacy, while being more likely to believe that they are financially literate.

Analyzing the cross correlations of responses to categories of financial literacy questions, facility with concepts related to the understanding of compound interest are found to have strong positive association with aggregate financial capacity measures spanning time-value of money, characteristics of financial markets, and federal Social Security program details.

Taken together these findings suggest that the financial planner-client relationship maybe very important for helping workers manage lump-sums as they plan and initiate retirement. In particular three types of tools can facilitate the development and persistence of successful planner-client relationships: (1) consumer targeted resources that help clients engage and assess the work of financial managers, (2) client intake surveys that include both self-assessments and objective questions addressing financial capability and (3) discussions and exercises facilitating client understanding of compound interest concepts. Those in private practice and public policy alike have a stake in developing the consumer guides, intake surveys and exercises of value.

\section{Literature Review}

Despite a growing literature in this area, some continue to debate what is meant by the term "financial literacy." This paper employs the definition: "the ability to use knowledge and skills to manage financial resources effectively for a lifetime of financial wellbeing," (President's Commission, 2009 p.4) where "use" speaks to both capacity and confidence. The emphasis on, "a lifetime of financial wellbeing," speaks to changes in resources and objectives across one's lifespan. (Note 1)

Elsewhere in the literature other groups have been targeted by age, organization, gender, cohort and culture: a college population for example (Chen and Volpe, 1998), young adults aged 22-28 (Lusardi, Mitchell and Curto, 2010), baby boomers (Lusardi and Mitchell, 2007), or workers in DC plans (Weisbenner, 2002 \& Seligman and Bose, 2012). (Note 2) Women have garnered a good deal of attention as a group in a number of areas related to personal financial behaviors. This study targets elder workers who are beginning to plan for the transition to retirement. Like Chen and Volpe (1998), Loibl and Hira (2011), or Malone et al. (2010) this work relies on data collected by the author and specific to the research. Like those focusing on females it focuses on traits, beliefs and behaviors as they correlate with financial capacity and self-assessment of capacity, separately. Also investigated here is the use of financial planners. A battery of many of the more popular personal habits elsewhere associated with assets and literacy are employed as controls. Like the Lusardi and Mitchell and the Seligman and Bose pieces the work here centers on measures created in or motivated by the Health and Retirement Study (HRS) (Thomas, 1992-2010). In accounting for the results of this study earlier findings on quasi-rational procrastination (O'Donoghue and Rabin, 2001) help explain muted engagement of financial planners, while work on 'cheap talk' (Farrell and Rabin, 1996) offers possible insights as to why self-motivated planning behaviors are found to impact self-assessment a good deal more than they do actual asset accumulation in this sample. The distinguishing contribution here is to document these attitudes and behaviors among a group of elder workers who have a strong incentive to learn how to manage a lump-sum distribution so as to best provide for their financial well-being in retirement.

The survey's financial literacy questions are based on a financial literacy module contained in the HRS and described in subsequent journal articles (for example, Lusardi and Mitchell, 2008) and one from the "Financial (il)literacy project" (Netspar CentER, 2005). Two appendices document particulars of these data. The first, Appendix A provides the full set of questions comprising the financial literacy survey module. Table Al provides the raw correlations between all scored questions and aggregate scores. The second, Appendix B describes questions that were added or amended in two areas: compound interest and annuity framing. The motivation for enhancing the testing of compound interest concepts found empirically in Appendix A, it is described further in the next section. The motivation for developing the additional annuity frame questions comes from recent work targeting annuity decisions in consumption versus investment frames (Agnew et. al. 2008 \& Brown et. al. 2008) and work on information management in investment decisions (Agnew and Szykman, 2005) Before discussing these further the survey method and data should be introduced. 


\section{Methodology}

The method employed surveys a population of U.S. workers approaching retirement to better understand individuals' financial position, and capacity to manage lump-sums as they retire. Participants were recruited with the help of human resource (HR) departments at three large employers in the health and education fields. All employers offered a DC plan. One of the employers segregated retirement plan options by employee type, some were relegated to a DB pension program and others chose between that plan and a DC plan. The DC plan of this employer could be fully cashed out, the DB plan allowed up to three years of benefits to be cashed out. All survey respondents face a lump-sum distribution decision.

Each HR department submitted a file of employees that included occupation, firm tenure, and plan tenure for each individual. The number of employees included in files submitted by each HR department was several times larger than the intended survey population of the study, to ensure the anonymity of respondents. A random subset of those agreeing to participate was interviewed.

The survey protocol was for face-to-face Computer Aided Personal Interviews (CAPI). (Note 3) Interviewers gathered data on personal attributes, preferences, and outlooks as respondents approach retirement. Interviews took place at the work site and were roughly 60-75 minutes in length; the final module consisted of a financial literacy quiz. Complete interviews were recorded for 353 participants. Interviews were conducted in a private room which was neither within the firms' HR department nor within the employees' home department to further protect participant anonymity. (Note 4) The survey instrument was designed to be comparable to the HRS: a biannual survey conducted by the National Institute on Aging (NIA) and administered by the University of Michigan's Survey Research Center.

While the sample does contain observations with low or negative net asset positions, much like the Survey of Consumer Finances (SCF), it is over-weighted towards high income, asset, and education populations. This offers an opportunity to observe how a population with adequate-to-significant wealth and income fare in terms of household financial behavior (as with the SCF). (Note 5)

The majority of survey responses were recorded between October 2007 and January 2008. No surveys took place later than February of 2008, prior to the brunt of labor market impacts of the Great Recession (2007-2009). (Note 6) Most general financial market impacts associated with the recession occurred in the fall of 2008. (Note 7)

Figure 1 depicts the distribution of respondents by year of birth (top panel), expected retirement ages (middle panel) and plots birth cohort by year of expected retirement for this sample (bottom panel).

\section{Insert Figure 1 here}

The sample is predominantly between 58-64 years of age at time of interview. A significant portion report not knowing when they will retire (17 percent), or decline to answer (3 percent). A gray bar marks the percent who report having expected to retire prior to the interview (12 percent, 15 percent of those reporting dates). A third, 33 percent, report an expected retirement date within a year of their interview ( 40 percent of those reporting a date). The bottom panel illustrates the relation between birth cohort and anticipated retirement date, the relationship is generally as one would expect in two important ways. First, the simple fitted value line documents a positive relationship between the two variables, and second a general focal mass appears near to the survey dates, across birth cohorts.

As documented in Appendix A's Table A1, scored questions are grouped in categories. Within each, the compound interest category is found to have the highest consistent correlation with aggregate scores (over 0.5 for each item). Elsewhere in the literature, Lusardi and Tufano (2009) have found that those who did not understand compounding were more prone to making bad borrowing decisions. Lusardi and Mitchell (2011) have found that people having experienced inflation were better at answering questions on inflation. Those who do not understand compounding and/or the time-value of money might reasonably be prone to have difficulty expressing their true preferences for consumption smoothing vehicles like annuities, particularly important for those about to retire. As principal is consumed, less remains to compound, thus managing longevity risk requires an appreciation of how declining wealth and compounding interact. Notably, the surveyed group is fairly adept at answering questions on compounding: 86 percent get the first question correct, 75 percent get the second (more difficult) question correct and 69 percent get both correct. Given the correlation with other categories of financial literacy questions, compound interest questions will be singled out for further investigation as part of later multinomial analysis.

A second enhancement in the survey instrument involves a suite of questions on preferences for the payout of hypothetical lottery winnings. (Lottery allocation is a synthetic and arguably benign frame from which to talk about lump-sum payment preferences.) These additions are intended to better identify respondents' latent annuitization 
preferences. The interested reader is directed to Appendix B for a fuller discussion of these questions' contribution to an understanding of how numeracy, frame and preferences motivate responders' lump-sum allocation strategies.

Because some of these additional questions are subject to preferences, not all can be graded as correct or incorrect. Overall, 12 of the questions found in Appendix A are scored. These are grouped into categories related to financial literacy: compound interest, time-value of money, characteristics of financial markets, and Social Security program details. Understanding of product and market information is important for managing finances. Similarly, Social Security, a public defined benefit program that offers a joint survivor inflation protected annuity, is important to understand for those looking to manage risk and return in financial markets. Without an understanding of Social Security, individuals may under or overconsume annuities, or otherwise misallocate portfolios.

One important subjective question included in Appendix A is the self-assessment question. Self-assessment should ideally be highly correlated to actual proficiency; however correlation between self-assessed and evidenced capacity is observed to be roughly 4 percent, suggesting that self-assessment is not a good proxy for financial capacity within this group.

The low correlation suggests people have trouble either in self-assessing or in announcing their assessment. Either bodes poorly for the idea that those who need help seek it openly. Stigma can damp participation in otherwise valuable activities (Moffitt, 1983). This is concerning as relates to uptake of financial or life counseling, perhaps especially in peer group environments, which employer-sponsored formats have tended to emphasize. Personal financial planners may be particularly valuable in these cases; however potential clients may quasi-rationally forgo selection and engagement of a planner through a series of reasoned postponements (O'Donoghue and Rabin, 2001). Whether due to overconfidence, stigma, a lack of understanding or motivation, many did not acquire knowledge in accordance with need prior to the survey.

Awareness of and willingness to admit to a deficiency are both generally seen as necessary for seeking help or advice--as such it is natural to distinguish between two vulnerable groups characterized as: -1- those who believe they lack the information and expertise by which to manage financial decisions as they retire and -2- those who show evidence of need but perceive themselves as capable--the overconfident. The groups may be distinguished comparing self-assessment and quiz scores.

Earlier studies have found that women are more likely to engage financial planners than men (Loibl and Hira, 2011). While women in these data display mild under performance and relative under confidence, their probability of meeting with a planner is statistically indistinguishable from that of men once assets and other controls are considered. By comparison non-white's display greater under performance, stronger overconfidence and are less likely to report meeting with a financial planner (38 percent as compared to 60 percent of whites). This pattern of evidence suggests that non-whites are most vulnerable being both over confident and least likely to seek professional help, whereas women in this group are much less so. White men (the reference group) are least vulnerable by this measure.

Of course distinguishing any relative vulnerability in this manner relies on the assumption that treatment, if sought, would be of benefit. Evidence supports that assumption. Among those reporting the highest degree of financial satisfaction 68 percent engage a financial planner. (Note 8) Use of a planner declines along the five-point satisfaction scale to 59 percent for the "somewhat" satisfied, 43 percent for those with neutral responses, and 18 percent for those reporting any level of dissatisfaction in these data. Notably, satisfaction with one's financial situation is a stronger predictor of financial capacity $(0.26)$ than self-assessment $(0.04)$, as measured by correlation with quiz score.

\section{Results}

Table 1 reports summary statistics for the full set of respondents, and for the modal number employed in regressions $(\mathrm{N}=278)$. Focus on the full sample supports work presented in Table 2, whereas the abridged sample better represents the population with a full set of responses required for inclusion in regression. The two samples are comparable. Each mean is well within the standard deviation of the other and vary by just a few percentage points.

\section{Insert Table 1 here}

Starting with variables relating to financial literacy, average performance is roughly 73 percent, or 8.7 correct answers for the 12 item quiz. Performance on compound interest type questions, averages 79 percent, though as one would expect, given the low resolution of any $\{0,1,2\}$ measure, there is a relatively high degree of variation about this mean. Within the remaining 10 questions average performance is roughly 71 percent. The survey population is over one-half female (56 percent) and just under one-quarter non-white $(23$ percent). Across the three distinct employers, one provides 48 percent of respondents; the remaining two provide 27 and 25 percent. The sample is 
by-and-large well educated, 96 percent complete high school; 70 percent hold a bachelor's degree and 53 percent hold a master's degree or doctorate. The sample is relatively balanced across DB and DC plans, 43 percent report holding a DB plan, 56 percent report a DC plan and 7 report both. Quiz scores averaged 73 percent for those with DB plans versus 76 percent for those with DC plans, these scores are statistically indistinguishable. When asked to self-assess proficiency with economics on a scale from 1-7, the mean score is 4.6 (66 percent).

Three questions estimate Arrow-Pratt measures of Constant Relative Risk Aversion. Consistent with recent use of this measure, a scaled four point ordinal measure is built for use in multivariate regression (Light \& Ahn, 2010); the mean of the Light-Ahn measure is 1.63 , between the most and second most risk adverse categories. The standard deviation is one full category (0.99).

Assets are computed as:

$$
A_{h h}=H+H^{\prime}+B+I R A+R i s k y+S a f e+C+I-D
$$

Where: $\quad A_{h h}=$ Household assets

$H \quad$ = Housing wealth net of outstanding mortgage(s)

$H^{\prime} \quad=$ Net value of other real estate holdings (Note 9)

$B \quad=$ Net value of any business owned within the household

IRA = Value of Individual Retirement Account (IRA)-type accounts

Risky $=$ Net value of stock + bond holdings

Safe = Sum of checking, money market, $\mathrm{CD}$ and US Treasury holdings

$C \quad=$ Value of any collections

I $\quad=$ Value of annuities held

$D \quad=$ Other obligations or unsecured debt.

Reported average assets are $\$ 2,843,748$. By the bottom panel of Table 1, the distribution is skewed.

The majority of this sample has a DC plan and the opportunity to select how their assets are invested. Slightly more than half report having participated in retirement planning meetings (54 percent). (Note 10) Active participation in DC plans and participation in employer-sponsored financial planning meetings are generally correlated with strong positive asset positions at time of retirement (Seligman and Bose, 2012). Very few in this sample find themselves holding net debt (a negative asset balance). But while mean asset levels are high, the standard deviation is nearly five times the mean. Employing a log-transform goes a long way towards standardizing these data, but regrettably discards four observations with negative net assets. Notably 77 percent of the survey population either has an IRA or has a spouse with one. These accounts facilitate the move of a DC balance, incremental increases in retirement savings, and tax planning. Figure 2 illustrates the sample distribution of reported assets ( $\left.A_{h h}\right)$.

Insert Figure 2 here

Figure two offers a fuller sense of the distribution than the bottom panel of Table 1.

Returning to Table 1, When queried about other retirement planning related activities of the sort found to be important elsewhere in the literature (Lusardi, 2000), 58 percent report having estimated their retirement needs at some point in the past. When queried on a four-point scale, the population as a whole reports having thought about retirement somewhere between "a lot" (1) and "some" (2), the mean being 1.7. Over three-quarters (78 percent) plan to work part-time in retirement, 58 percent report having a savings plan for retirement. When asked about budgeting, the population as a whole reports keeping track of spending somewhere between "always" (1) and "mostly" (2), the mean being 1.85. Generally the sample is "somewhat" (2) satisfied with their financial situation, the mean being 1.99. When asked about their planning period, the sample reports somewhere between "the next few years" (3) and the "next five to ten years" (4), the mean being 3.22. The table's bottom panel offers a fuller distribution of financial literacy test scores, self-assessments, and assets.

\section{Bivariate data analysis}

Table 2 presents cross tabulations of test performance by education and wealth.

Insert Table 2 here

Regarding education, there is a natural break in test performance at the bachelor's degree (BA) level. Those holding a BA perform 22 percentage points better on average (79 percent versus 57 ), a difference that is highly statistically 
significant as reported by a calculated t-statistic for unequal samples of 9.2. Looking at achievement in terms of thresholds for performance, 42 percent of those with a BA score 90 percent or better on the test as compared to just 10 percent of those without. (Note 11) Considering an 80 percent score threshold, the less-than-BA sample achieves at that level less than one-quarter as frequently (15 percent versus 65). (Note 12)

Table 2 documents test scores by level of assets. It will likely come as no surprise that those with the lowest asset balances do relatively poorly on the 12 item quiz. Separating the sample at the $25^{\text {th }}$ percentile of the asset distribution yields a 14 point difference in scores, highly statistically significant. Separating groups at the median asset level, magnitudes are still meaningful though they differ by roughly half as much. Considering score thresholds, 65 percent of those with above-median assets score 80 percent or better on the test while just 35 percent of those with asset levels below the median achieve at this level. What may surprise the reader is how groups in the middle and top asset groups differ by score. The 90 percent achievement threshold is met by 45 percent of the above-median asset group, but only 19 percent of the below-median asset group. An alternate asset cut-off at the $66^{\text {th }}$ percentile suggests that the median cut-off is most useful for distinguishing levels of facility with quiz concepts. Another such cut-off emerges at the $90^{\text {th }}$ percentile of the asset distribution. Mean scores by group are 76 percent for those below the top wealth decile, but only 46 percent within it--the largest identified disparity across groups and one which is quite statistically significant. The vulnerability of this high wealth group is seen across performance thresholds as well; 10 percent of the high asset group receive an 80 or better, while only 5 percent achieve a 90 or better on the test--notably worse than the below median group. In short, the top 10 percent do worse than the bottom half of the wealth distribution, indicating that vulnerability exists among the top wealth decile. This vulnerability may be an artifact of having taken success as evidence of capacity, when it actually had more to do with luck. (Note 13)

The bottom panel of Table 2 helps highlight differences between objective and subjective experiences across groups. Comparing the top and bottom panels the relative lack of variation in self-assessment across groups is notable. Considering education, within the bottom panel those with a BA have both somewhat higher and more consistent self-reports. When coupled with the top panel this describes an observably lower risk of over-confidence among those with a BA. Comparisons by asset level yield weak differences in self-assessment across most asset thresholds, with one exception. The top ten percent of the wealth distribution is most inclined to report a self assessed proficiency at the 90 percent level or higher (15.9 percent). This group over-predicts test performance by way of self-assessment by about 20 percentage points (average quiz score of 46 percent versus average self-assessment of 66 percent). Self-assessed proficiencies at either the $80^{\text {th }}$ or $90^{\text {th }}$ percent level occur at more than three times the rates of test scores. All of these differences are statistically significant. To summarize, the sample is not good at self-assessment; those with the greatest assets display over-confidence.

The next section reports on three sets of related multivariate regressions to help better understand relationships between test scores and population characteristics.

\section{Multivariate Data Analysis}

Reducing the risk of spurious correlation attributable to omitted variables allows one to get a better sense of the strength of the relationships reported so far. Because the dependent variables are censored that is to say that we observe individuals with score values at both extremes of each dependent variable scale, the two-sided Tobit is the appropriate model for analysis. Here the basic regression model is:

$$
y_{n}^{*}=X_{n} \beta+\varepsilon_{n}
$$

Where the dependent variable $y_{n}^{*}$ is observed when it is above the lower limit (0) and below the upper limit (1), otherwise the limits are observed. The intuition here is simply that a score of " 0 percent" or " 100 percent" on this test does not imply that the individual would receive the same score on alternate related tests. (Note 14) In the models here dependent variables $y_{n}^{*}$ are: two related percentage measures of performance on the quiz, and one percentage measure of self-assessment. (Note 15) Table 1 details all dependent variables, $y^{*}$, and independent variables included in $\{X\}$ for the regression sample $(N=278)$. Measures of the power of the regressions consistently yield a chi-squared measure of 130-170 meaning that together the regressors strongly statistically relate to the dependent variable $\left(99^{\text {th }}\right.$ percentile confidence or better). (Note 16) Table 3 summarizes main results from work with all three dependent variables affording readers the opportunity to compare central results from each.

\section{Insert Table 3 here}

Column one of this table is drawn from column 4 of Table 4 . The dependent variable is constructed from responses to a 12 item financial literacy quiz. Column 2 is similarly drawn from Table 5 where the dependent variable employs 
an augmented 10 item measure. The third column of this table is from Table 6, it employs the measure of self-assessment as the dependent variable.

Generally, the reader is encouraged to consider results in Table 3 as follow: Column 1 establishes central results regarding attributes associated with an improved score over the full set of financial literacy questions. Measures of $\mathrm{R}$-squared suggest roughly 40 percent of variation in the 12 item score is captured by included regressors. Given the discussion of compound interest above, the second column strips the two compound interest questions from the dependent variable and treats their score as an additional regressor/control. This allows one to account for the role of compound interest questions directly and to compare results for all other independent variables as a robustness check on those findings. (Note 17) Measures of R-squared generally improve, suggesting that 46 percent of variation is described by the model, findings otherwise generally hold. The last column contrasts predictors of self-assessment. Measures of R-squared here decline to suggest the regression model captures only 20 percent of variation in assessment. Taken together, these specifications afford insight on financial literacy for those preparing to manage lump-sum distributions. Tables 4-6 enhance understanding of these relationships as they employ alternate related specifications as robustness checks to the findings in Table 3.

\section{Insert Table 4 here}

In Table 4 all specifications include gender, race, employer fixed-effects, education, self-reported proficiency in economics, understanding of compound interest, risk preference, assets, and several behaviors associated with self-control and improved financial management documented elsewhere in the literature (Lusardi, 2000 \& Mastrobuoni and Weinberg, 2009). Specifications employ a log-asset measure to allow consideration of variation in education specifications 1-3. Specifications 5-7 hold the education side fixed, with a binary break at the BA level to allow variation in the treatment of assets to be explored. Specification 4, in the middle of the pack uses the preferred variables for assets and education, the one presented in Table 3.

Insert Table 5 here

Beginning at the top, results from tables 4 and 5 reveal that female and non-white participants scored lower on financial literacy questions than other participants by roughly 5-8 percentage points for females and 10-16 percentage points for non-whites. This is consistent with Alessie et. al. (2011). Here observed achievement gaps for non-whites are notably larger, while results for both groups are statistically robust. Table 5 evidences a decline in females under-performance, narrowing the gap to 4-7 percent outside of compounding concepts. By contrast, when compared to white respondents, non-white respondents underachieved by 11-15 percent on the 10 item score. The statistical significance assigned to these measured differences is consistently strong. By Table 6 females mildly overstated their lesser understanding by 2-3 percentage points relative to actual performance; here they consistently self-assessed a statistically significant 8-10 percent lower than the control population. These are relatively minor differences, but they can be interpreted as either reassuring (i.e. things are generally better for females than self-reports suggest), or as concerning (i.e. females lack adequate belief in their ability to make financial decisions). This latter interpretation is in line with the importance of wealth in increasing self-esteem, and commensurate concerns in light of reduced asset accumulation among women (Lusardi and Mitchell, 2008 \& Saunders and Porterfield, 2009). (Note 18) The reader should note however that the significance of this finding is attenuated by differences in scale.

Results for non-whites are of particular concern. Controlling for all other characteristics non-whites overestimated their capacity and underperformed the reference group by broad margins; self-assessing 12-18 percentage points higher while scoring 10-16 percentage points lower on the test. Statistical significance for these measures pass the 99 percent confidence level. Concern is unambiguous, non-whites appear over-confident in their capacity to evaluate financial decisions, and generally displayed a need for services (by tables 4 and 5) they were disinclined to perceive or report (by Table 6).

\section{Insert Table 6 here}

In keeping with evidence presented in Table 2, several different measures of education and assets were tested within the panel of specifications in Table 6. Education was considered as follows: The first specifications of tables 4 and 5 report a baseline linear rate that suggests each additional year of education increased correct answers on the test by 1-2 percentage points. The way education and self-assessment correspond is less well described (Table 6); estimated effects were negative, small, and statistically insignificant. Test results suggest that linear estimates are not as important once degree attainment is considered. Those with less than a BA consistently scored lower by 5-9 percent (tables 4 and 5). Considering compound interest (Table 5), those with a BA performed on average nearly one-half 
question (22 percentage points) better than those without the degree. (Note 19) Results between tables 3 and 4 varied slightly by specification; in some instances the impact of a BA was marginally more or less attributed to compound interest questions. Consistent differences of between 9-12 percent appear in Table 4; 1-2 percentage points more than in Table 5. Overall, successfully answering both compound interest questions is correlated with improvements across the rest of the test that are roughly double that associated with a BA. This suggests a relatively compact remedial education can be useful. (Note 20)

Remarkably, by Table 6 education has no significant impact on self-assessed understanding. Further, neither compound interest nor other quiz questions were found to inform self-assessment after controlling for other factors. One can observe weak evidence that more capable quiz takers may have understated their proficiency relative to less capable performers. Overall, late career workers facing lump-sum allocation decisions are found to have a very poor sense of their financial capacity.

Success with the compound interest questions was quite strongly correlated with success across the remaining 10 questions. The coefficients imply that for each compound interest question answered correctly, scores might be expected to have increased by 8-10 additional percentage points across the remainder of the test; this result is statistically significant. Compound interest problems require a person to manage several changing elements in any single calculation, and arguably are very important at the time surrounding retirement. In particular, compound interests calculations are required for assessing annuity returns; these in turn should inform purchase decisions. (Note 21)

Greater risk aversion was strongly associated with better quiz scores, by a magnitude of roughly 2 percentage points per up-tick in the constructed four point risk-aversion scale. As the reader might anticipate the dynamic differs for self-assessment, the less risk adverse tended to report higher self-assessment, though the results were not statistically robust.

The effects of assets were explored in a variety of ways. For each increase in the log value (approximating a factor increase), test scores improved by 2-3 percentage points across Table 4; Table 5's weaker results imply that variation in compound interest scores drive a large proportion of the variation.. Further regarding wealth, specification 5 in tables 3 and 4 offer about a five percent underperformance of those in the top decile, though the result is not at all statistically robust. However specifications 6 and 7 in tables 4 and 5 find those in the top decile who use financial planners underperform by 10-13 percent, robust at the 95 percent level. Table 6 may help the reader to distinguish between underperformance and over-confidence; the top decile is 16 percent more confident (column 5, significant at the 99 percent level), but this is not associated with the use of a planner (columns 6 and 7). IRA ownership fails to be significantly correlated with test scores or self-assessed understanding.

Elsewhere in the literature variables like the reported existence of a savings plan, whether people keep track of spending, and the amount people have thought about retirement have been found to be important for outcomes and to relate to literacy (Lusardi, 2000, Lusardi and Mitchell, 2007 \& Alessie et. al., 2011). The last battery of regressors acts as control for these habits, behaviors, attitudes and plans. None of the factors are found to be uniquely significantly related to quiz scores. However Table 6 does highlight a few notable correlates with self-assessment. Each increase in reported satisfaction with one's financial situation corresponds to a statistically strong 3 percentage point increase in self-assessment. Otherwise remaining evidence is weak. In one case (specification 5) estimating retirement need is weakly correlated with a 7 percent increase in assessment. There is weak evidence that increases in the amount thought about retirement correspond to about a 3 percentage point increase in assessment; that those who attend meetings on retirement assess 4 percentage points lower; lengthening of planning periods is weakly associated with increase assessment by a couple of percentage points.

\section{Conclusion}

The objective of this work has been to improve understanding of financial literacy at the cusp of retirement using a unique sample in terms of employment, assets, education and participation in plans mandating a decision on the treatment of a partial or full lump-sum retirement benefit. Respondents are generally very well educated and report wealth sufficient for retirement. However, they demonstrate observable and predictable shortfalls in their capacity to manage their finances; by that standard they are vulnerable to financial hardship during the course of their retirement. Given that a relatively educated and well-off group does not perform consistently well on a basic financial literacy test, expectations that the broader population has capacity to mange lump-sum distributions should be lower than otherwise. That noted the increased likelihood of managing a lump-sum retirement benefit, and the findings here suggest that financial education targeted to elder workers has the potential to improve wellbeing in retirement. Findings further suggest that a remedial education focused on basic tasks such as application of compound interest 
calculations may motivate knowledge acquisition in other important financial literacy categories. Facility with the compound interest question battery is found to have strong positive association with aggregate financial capacity measures spanning time-value of money, characteristics of financial markets, and Social Security program details.

Regarding self-assessment, the analyses here find that more educated and more knowledgeable quiz takers are more likely to understate their knowledge while performing at a level equal to or better than comparison groups. By contrast non-whites and those with assets in the top decile hold test scores and self-assessments that suggest over-confidence. The general lack of correlation between quiz scores and self-assessments supports the idea that both measures together help document overconfidence. Documented overconfidence may motivate individuals' interest and participation in financial education.

Three asset groups have been distinguished, the lowest quartile, those below median assets and the top wealth decile. Female and non-white groups can also be distinguished from white males in terms of both self assessed and evidenced facility with financial decisions. Customizing offerings across these groups may best tailor information to context, and further improve motivation among potential participants. Related to this, individuals inclined to purchase personal financial planning services are likely to appreciate applied contextual education that improves their ability to monitor, evaluate, and manage relationships with financial planners. Finally, where under-confidence is evidenced by consideration of both self-assessed and actual performance a primary objective of research in financial security should be to increase comfort with financial decisions--ill-founded concerns form an important basis for opportunity along these lines.

\section{Acknowledgements}

David Richardson, Bruce Weinberg, David Blau, Audrey Light, Stephanie Moulton, Jeffrey Wenger, Ryan Edwards, Julie Agnew, Annamaria Lusardi, Olivia Mitchell, Karen Holden, Michael Collins and seminar participants at the University of Wisconsin, Queens College and the Ohio State University all provided helpful comments at various stages of the work. Richard Clark helped with survey design and field implementation, Rana Bose provided research assistance.

All persons surveyed gave their informed consent in two separate instances prior to their inclusion in the study. All human studies have been approved by the appropriate ethics committee, The Institutional Review Board of the University of Georgia, over the course of time that this research was conducted. Details that might reveal the identity of persons surveyed have been omitted. The research has therefore been performed in accordance with the ethical standards laid down in the 1964 Declaration of Helsinki.

This research was supported by an anonymous funder for whom I am appreciative.

The author declares that he/or/she has no conflict of interest.

\section{References}

Alessie, R. Van Rooij, M., \& Lusardi, A. (2011). Financial Literacy and Retirement Preparation in the Netherlands. Journal of Pension Economics and Finance, 10(4), 527-545. http://dx.doi.org/10.1017/S1474747211000461

Agnew, J., Anderson, L., Gerlach, J., \& Szykman, L. (2008). Who Chooses Annuities?: An Experimental Investigation of Gender, Framing and Defaults. American Economic Review, 98 (2), 418-422. http://dx.doi.org/10.1257/aer.98.2.418

Agnew, J., \& Szykman, L. (2005). Asset Allocation and Information Overload: The Influence of Information Display, Asset Choice, and Investor Experience. The Journal of Behavioral Finance, 6 (2), 57-70. http://dx.doi.org/10.1207/s15427579jpfm0602_2

Aguiar, M., \& Hurst, E. (2005). Consumption versus Expenditure. Journal of Political Economy, 113 (5), 919-948. http://dx.doi.org/10.1086/491590

Brown, J., Kling, J., Mullainathan, S. and Wrobel, M. (2008). Why Don't People Insure Late Life Consumption? A Framing Explanation of the Under-Annuitization Puzzle. The American Economic Review, (98) 2, 304-309. http://dx.doi.org/10.1257/aer.98.2.304

Chen, H., \& Volpe, R. P. (1998). An Analysis of Personal Financial Literacy among College Students. Financial Services Review, 7(2), 107-128. http://dx.doi.org/10.1016/S1057-0810(99)80006-7

Farrell J., \& Rabin, M. (1996). Cheap Talk. Journal of Economic Perspectives, 10(3), 103-118. http://dx.doi.org/10.1257/jep.10.3.103

Gale, W. G., Harris, B.H., \& Levine, R. (2012). Raising Household Saving: Does Financial Education Work? Social Security Bulletin, 72(2), 39-48.

Gruber, J., \& Madrian, B.C. (2004). Health Insurance, Labor Supply, and Job Mobility: A Critical Review of the Literature, in Catherine McLaughlin, ed., Health Policy and the Uninsured. Washington, D.C.: Urban Institute Press, 97-178. 
Light, A., \& Ahn, T. (2010). Divorce as Risky Behavior. Demography, 47(4), 895-921. http://dx.doi.org/10.1007/BF03213732

Loibl, C., \& Hira T. K. (2011). Know Your Subject: A Gendered Perspective on Investor Information Search. Journal of Behavioral Finance, 12 (3),117-130. http://dx.doi.org/10.1080/15427560.2011.600841

Lusardi, A.. (2000). Saving for Retirement: the Importance of Planning, Research Dialogue, TIAA-CREF Institute, 66, 2000.

Lusardi, A., \& Mitchell, O.S. (2007). Baby Boomer Retirement Security: The Roles of Planning, Financial Literacy, and Housing Wealth. Journal of Monetary Economics, 54, 205-224. http://dx.doi.org/10.1016/j.jmoneco.2006.12.001

Lusardi, A., \& Mitchell, O.S. (2008). Planning and Financial Literacy. How Do Women Fare? American Economic Review, 98(2) 413-417. http://dx.doi.org/10.1257/aer.98.2.413

Lusardi, A., \& Mitchell, O.S. (2011). Financial Literacy Around the World: an Overview. Journal of Pension Economics and Finance, 10(4), 497-508. http://dx.doi.org/10.1017/S1474747211000448

Lusardi A., \& Tufano, P. (2009). Debt Literacy, Financial Experiences, and Overindebtedness. NBER Working Paper No. 14808.

Malone, K., Stewart, S.D., Wilson, J. Korsching P. (2010). Perceptions of Finacial Well-Being among American Women in Diverse Families. Journal of Family and Economic Issues, 31(1), 63-81. http://dx.doi.org/10.1007/s10834-009-9176-5

Mastrobuoni, G., \& Weinburg, M. (2009). Heterogeneity in Intra-Monthly Consumption Patterns: Self-Control and Savings American Economic Journal: Economic Policy, 1(2). 163-189. http://dx.doi.org/10.1257/pol.1.2.163

Moffit, R. (1983). An Economic Model of Welfare Stigma, American Economic Review, 73(5), 1023-1035.

Netspar CentER (2005). Financial (il)literacy project. Tilburg, Netherlands: Authors.

O'Donoghue, Ted and Matthew Rabin (2001). Choice and Procrastination, Quarterly Journal of Economics, 116(1), 121-160. http://dx.doi.org/10.1162/003355301556365

President's Advisory Council on Financial Literacy (2009). 2008 Annual Report to the President. Office of Consumer Policy, Department of Treasury, United States.

Sawtooh Survey Interview Software (2007). Ci3 CAPI system. Sequim, WA: Authors.

St.Clair, P., Blake, D., Bugliari, D. Chien, S. Hayden, O., Hurd, M. et. al. (2008). RAND HRS Data, Version H Data Documentation. Produced by the RAND Center for the Study of Aging, with funding from the National Institute on Aging and the Social Security Administration. Santa Monica, CA.

Saunders, C. K., \& Porterfield, S. L. (2010). The Ownership Society and Women: Exploring Female Householders' Ability to Accumulate Assets. Journal of Family and Economic Issues, 31(1), 90-106. http://dx.doi.org/10.1007/s10834-009-9175-6

Seligman, J. S. (2010). Missing the Mark: Employment Related Risks to Retirement Security for Older Workers. TIAA-CREF Policy Briefs.

Seligman, J. S., \& Bose, R. (2012). Learning by Doing: Active Employer Sponsored Retirement Savings Plan Participation and Household Wealth Accumulation The Quarterly Review of Economics and Finance, 52(2), $162-172$.

Thomas, J.F. (Primary Investigator). (1992 - 2010). Health and Retirement Study, public use dataset. Produced and distributed by the University of Michigan with funding from the National Institute on Aging (grant number NIA U01AG009740). Ann Arbor, MI.

Weisbenner, S. J. (2002., Do Pension Plans with Participant Investment Choice Teach Households to Hold More Equity? Journal of Pension Economics and Finance, 1(3): 223-248. http://dx.doi.org/10.1017/S1474747202001129

\section{Notes}

Note 1. This is but one example of a sufficient definition. For example an alternate definition: "financial literacy assesses one's ability to understand basic economic principles as well as confidence in discussing financial matters, awareness of risk, and skill at managing finances and assessing financial resources" (Malone et. al., 2010 p.64) is also fine.

Note 2. Both of these studies target employer based financial literacy offerings. As summarized in Gale et. al. (2012) employer based education has been a relatively productive platform for improving financial literacy.

Note 3. Survey protocols were vetted by and adhere to the University of Georgia's IRB protocol for human subjects. 
Note 4. This was a particularly important consideration for private employers who were concerned that knowledge of the identities of subjects would leave them liable to suit if participants were later passed over for a raise, a promotion, or let go. To provide consistency in recruitment the method was the same for all three sites.

Note 5. Median asset values for the population surveyed here are between the SCF working and retired population measures documented in Fisher and Montalto (2010).

Note 6. According to the Bureau of Labor Statistics Southeast Information Office, the region in which these data were collected did not experience absolute declines in employment until May of 2008.

Note 7. See for example the evolution of Dow Jones' Industrial Average, or Standard \& Poors' S\&P 500. The bankruptcy of Lehman Brothers on September 15, 2008 is generally acknowledged as the watershed event that precipitated a generally tightening of liquidity leading to the slowdown of consumption, production and employment in months to come.

Note 8. As measured by the survey question: "Next, I am going to ask about your satisfaction or dissatisfaction with various aspects of your life at the CURRENT TIME. Are you very satisfied, somewhat satisfied, about evenly satisfied and dissatisfied, somewhat dissatisfied, or very dissatisfied ....with your financial situation"

Note 9. The only substantive difference with data collected for the HRS is with respect to a second residence. Here they are coded as part of , whereas they are not consistently coded in the HRS (St. Clair et. al., 2008).

Note 10. Of note, those who reported expected retirement dates in the past had a much higher rate of attendance at such meetings roughly 66 percent of them had attended such a meeting as compared to 55 percent of those expecting to retire in the future suggesting that the meetings may have informed their decision to delay retirement. This evidence is merely suggestive however, a t-test for unequal samples across the binary query regarding attendance of such meetings is not at all compelling, it yields a t-stat of 0.45 .

Note 11. The advanced degree population does not do significantly better on tests than the larger BA-or-better group. Regression results found later in this report will confirm this.

Note 12. In additional exploratory counts not included here, the lower education population is more likely to report not knowing the answer to one or more questions; 60 percent of those without a BA answer "don't know" at least once, compared to 30 percent for those with a BA.

Note 13. The vulnerability may be manifest in any number of ways, for example when monitoring the performance of professional financial advisers, a Principal-Agent type problem. It may also manifest, for example, as a result of an insistence to self-manage assets when a professional would better safeguard wealth. There are no doubt many other pathways for this latent vulnerability to manifest.

Note 14. For example conditional on receiving a score of $0: 10$ ( 0 percent correct) on a ten item test one might receive any score within $\{0,1,2\}: 12$ on the same test with two additional items. At the upper limit, conditional on receiving a perfect score of 10:10 (100 percent correct), one might receive $\{10,11,12\}: 12$ score on the expanded test.

Note 15. In alternate specifications raw score Tobit specifications were substituted for the percentage transform, results are essentially the same, but are arguably more difficult to interpret as a group because of variation in the dependent variable scales (these being: 12, 10, and 7 across the three dependent specifications).

Note 16. The chi-squared here is analogous to the F-statistic seen in a traditional non-censored regression (for example, ordinary least squares). Of particular note, by the chi-squared, r-squared, and stability of individual t-tests the sample size is found to be adequate for identification. Further, no severe multicollinearity or heteroscedasticity appears likely conditional on the specifications employed. (For more on the Tobit Model see Greene, 2003, p. 762-780, and regarding chi-squared calculations see p. 776-777).

Note 17. Specifically, comparing coefficients on like independent variables between tables 3 and 4 gives a sense of the sensitivity of the relationship between the differing dependent variables (with versus without embedded compound interest questions) and each independent variable. The Table 5 dependent variable excludes compound interest scores and a new independent compound interest variable soaks up the variation across the remaining 10 items identified to be best attributed to compound interest concept scores. To see an example of this consider the difference between female and male scores Comparing results suggests that differences between females and males on the full 12 item quiz are attributable in good part to performance on compound interest questions.

Note 18. The data here document lower assets among female respondents at time of interview. Within this sample median female reports of assets were $\$ 416,000$ versus $\$ 784,000$ for males (53 percent). At the 99 th percentile of the distributions observed assets were $\$ 32.3$ million versus $\$ 56.4$ million (57 percent). At the opposite end of the spectrum (1st percentile) male respondents reported \$56,000 in asset balances, versus debt of $\$ 75,000$.

Note 19. Average scores by group are 1.71 with a BA versus 1.29 without. In percentage terms the scores differ by 22 percentage points, statistically significant within the 99 percent confidence interval. 
Note 20. The teaching of compound interest concepts is remedial in the sense that it remedies a deficiency that arguably prohibits inquiry and aptitude across a number of related financial concepts.

Note 21. A natural further exercise regards budgeting. Mastrobuoni and Weinberg (2009) find a significant portion of those with low savings fail to budget their monthly Social Security checks while Aguiar and Hurst (2005) have found evidence that retirement income needs fall in part due to home production, coupon-clipping, etc. Together these highlight the value of organization and budgeting for well-being in retirement.

Table 1. Summary statistics

\begin{tabular}{|c|c|c|c|c|c|c|c|}
\hline & & & & & & $\mathrm{N}=278 \mathrm{sa}$ & ample \\
\hline Variable & Obs & Mean & Std.Dev. & Min & Max & Mean & Std.Dev. \\
\hline financial lite racy quiz score (out of 12) & 353 & 8.70 & 2.74 & 0.00 & 12.00 & 9.23 & 2.28 \\
\hline " in percentage terms (proportion: l) & 353 & 0.73 & 0.23 & 0.00 & 1.00 & 0.77 & 0.19 \\
\hline performance on compound interest questions $(0,1,2)$ & 353 & 1.58 & 0.67 & 0.00 & 2.00 & 1.67 & 0.58 \\
\hline "inpercentage terms (proportion: 1) & 353 & 0.79 & 0.33 & 0.00 & 1.00 & 0.84 & 0.29 \\
\hline score (without compound interest questions, : 10) & 353 & 7.12 & 2.32 & 0.00 & 10.00 & 7.56 & 1.97 \\
\hline female (proportion: l) & 353 & 0.56 & 0.50 & 0.00 & 1.00 & 0.56 & 0.50 \\
\hline nonwhite(proportion: 1) & 353 & 0.23 & 0.42 & 0.00 & 1.00 & 0.19 & 0.40 \\
\hline prime employer (proportion:l) & 353 & 0.48 & 0.50 & 0.00 & 1.00 & 0.50 & 0.58 \\
\hline alternate private employer (proportion: 1) & 353 & 0.27 & 0.44 & 0.00 & 1.00 & 0.25 & 0.43 \\
\hline alternate educationalemployer (proportion: 1) & 353 & 0.25 & 0.43 & 0.00 & 1.00 & 0.25 & 0.43 \\
\hline Education & 352 & 12.28 & 2.69 & 1.00 & 15.00 & 12.56 & 2.34 \\
\hline less than highschool (proportion: 1) & 352 & 0.04 & 0.20 & 0.00 & 1.00 & 0.02 & 0.13 \\
\hline less than bachelors degree (proportion: 1) & 352 & 0.30 & 0.46 & 0.00 & 1.00 & 0.27 & 0.44 \\
\hline less than advanced deggree (proportion: 1 ) & 352 & 0.47 & 0.50 & 0.00 & 1.00 & 0.46 & 0.50 \\
\hline self assessed proficiency with economics $\{(\min ) 0, . ., 7(\max )\}$ & 344 & 4.60 & 1.50 & 1.00 & 7.00 & 4.67 & 1.47 \\
\hline "in percentage terms (proportion: l) & 344 & 0.66 & 0.21 & 0.14 & 1.00 & 0.67 & 0.21 \\
\hline Light-Ahn CRRA measure \{most risk adverse $1, . ., 4$ least $\}$ & 326 & 1.63 & 0.99 & 1.00 & 4.00 & 1.61 & 0.99 \\
\hline assets (in tens of thousands of dollars) & 317 & 284.37 & 931.67 & -7.50 & $10,689.00$ & 259.90 & 920.72 \\
\hline log value of assets & 313 & 13.30 & 1.56 & 9.21 & 18.49 & 13.23 & 1.52 \\
\hline IRAownership (self e/or spouse) & 346 & 0.77 & 0.42 & 0.00 & 1.00 & 0.79 & 0.40 \\
\hline reporthaving estimated retirement need (proportion: 1) & 349 & 0.58 & 0.49 & 0.00 & 1.00 & 0.60 & 0.49 \\
\hline amount thought about retirement $\{$ a lot $1, . ., 4$ hardly at all $\}$ & 351 & 1.70 & 0.85 & 1.00 & 4.00 & 1.65 & 0.82 \\
\hline attended meetings on retirement (proportion: 1 ) & 351 & 0.54 & 0.50 & 0.00 & 1.00 & 0.56 & 0.50 \\
\hline plan to work part time in retirment (proportion: l) & 339 & 0.78 & 0.41 & 0.00 & 1.00 & 0.77 & 0.42 \\
\hline have a savings plan for retirement (proportion: 1) & 349 & 0.58 & 0.44 & 0.00 & 1.00 & 0.60 & 0.44 \\
\hline keep track of spending $\{$ always $1, . .$, never 4$\}$ & 348 & 1.85 & 0.92 & 1.00 & 4.00 & 1.88 & 0.93 \\
\hline satisfied with financial situation $\{$ most $1, . ., 5$ least satisfied $\}$ & 349 & 1.99 & 0.98 & 1.00 & 5.00 & 1.96 & 0.94 \\
\hline planning period: $\{$ the next month $1, . ., 5$ more than tenyrs\} & 339 & 3.22 & 1.21 & 1.00 & 5.00 & 3.23 & 1.22 \\
\hline
\end{tabular}

\begin{tabular}{|c|c|c|c|c|c|c|c|c|c|}
\hline distribution detail -- distribution percentiles & 1 & 5 & 10 & 25 & 50 & 75 & 90 & 95 & 99 \\
\hline score (with compound interest questions) & 0.0 & 3.6 & 5.0 & 7.0 & 9.0 & 11.0 & 12.0 & 12.0 & 12.0 \\
\hline "in percentage terms (proportion: 1) & 0.0 & 0.3 & 0.4 & 0.6 & 0.8 & 0.9 & 1.0 & 1.0 & 1.0 \\
\hline score (without compound interest questions) & 0.0 & 3.0 & 4.0 & 6.0 & 8.0 & 9.0 & 10.0 & 10.0 & 10.0 \\
\hline self assessed proficiency witheconomics $(0,7(\max ))$ & 1.0 & 1.0 & 3.0 & 4.0 & 5.0 & 6.0 & 6.0 & 7.0 & 7.0 \\
\hline "in percentage terms (proportion: 1) & 0.1 & 0.1 & 0.4 & 0.6 & 0.7 & 0.9 & 0.9 & 1.0 & 1.0 \\
\hline assets (in tens of thousands of do llars) & 0.0 & 5.2 & 9.2 & 21.0 & 53.6 & $1,262.0$ & $4,012.0$ & $1,529.1$ & $4,598.0$ \\
\hline log value of assets & 9.7 & 11.0 & 11.6 & 12.3 & 13.2 & 14.1 & 15.2 & 16.5 & 17.6 \\
\hline
\end{tabular}


Table 2. Test performance and self-assessment by education, and assets

\begin{tabular}{|c|c|c|c|c|c|}
\hline \multirow{2}{*}{$\begin{array}{l}\text { Test Performance } \\
\text { by group characteristics }\end{array}$} & \multirow{2}{*}{ mean } & \multirow{2}{*}{$\begin{array}{l}\text { sample } \\
\text { variance }\end{array}$} & \multirow{2}{*}{$\begin{array}{c}\mathrm{t} \text {-test } \\
\text { unequal } \\
\left\{N, \sigma^{2}\right\}\end{array}$} & \multicolumn{2}{|c|}{ percent scoring above } \\
\hline & & & & $80 \%$ & $90 \%$ \\
\hline Overall: & $72.5 \%$ & $5.1 \%$ & & $50.0 \%$ & $32.4 \%$ \\
\hline \multicolumn{6}{|l|}{ By Education: } \\
\hline less than Bachelors degree & $57.4 \%$ & $4.1 \%$ & & $14.6 \%$ & $9.7 \%$ \\
\hline Bachelors degree or greater & $79.1 \%$ & $4.1 \%$ & 9.17 & $64.7 \%$ & $41.8 \%$ \\
\hline \multicolumn{6}{|l|}{ By Assets: } \\
\hline first quartile & $61.6 \%$ & 0.03542 & & $20.0 \%$ & $11.3 \%$ \\
\hline greater than first quartile & $75.7 \%$ & 0.05274 & 5.62 & $58.6 \%$ & $38.5 \%$ \\
\hline lower than median & $68.8 \%$ & $3.7 \%$ & & $34.5 \%$ & $18.8 \%$ \\
\hline median level or greater & $75.9 \%$ & $6.2 \%$ & 2.98 & $64.7 \%$ & $45.1 \%$ \\
\hline lower tho treciles & $73.3 \%$ & $3.7 \%$ & & $48.7 \%$ & $29.1 \%$ \\
\hline top thrid & $71.4 \%$ & $8.4 \%$ & 0.62 & $53.9 \%$ & $40.0 \%$ \\
\hline lower nine deciles & $75.8 \%$ & $4.0 \%$ & & $54.8 \%$ & $35.7 \%$ \\
\hline top decile & $46.2 \%$ & $7.4 \%$ & 8.18 & $10.3 \%$ & $5.1 \%$ \\
\hline
\end{tabular}

\begin{tabular}{|c|c|c|c|c|c|}
\hline \multirow{2}{*}{$\begin{array}{l}\text { Self-Assessment } \\
\text { by group characteristics }\end{array}$} & \multirow{2}{*}{ mean } & \multirow{2}{*}{$\begin{array}{l}\text { sample } \\
\text { variance }\end{array}$} & \multirow{2}{*}{$\begin{array}{c}\mathrm{t} \text {-test } \\
\text { unequal } \\
\left\{N, \sigma^{2}\right\}\end{array}$} & \multicolumn{2}{|c|}{ percent reporting above } \\
\hline & & & & $80 \%$ & $90 \%$ \\
\hline Overall: & $64.9 \%$ & $4.5 \%$ & & $26.4 \%$ & $8.6 \%$ \\
\hline \multicolumn{6}{|l|}{ By Education: } \\
\hline less than Bachelors degree & $61.8 \%$ & $6.0 \%$ & & $25.7 \%$ & $11.4 \%$ \\
\hline Bachelors degree or greater & $66.3 \%$ & $3.9 \%$ & 1.66 & $26.7 \%$ & $7.4 \%$ \\
\hline \multicolumn{6}{|l|}{ By Assets: } \\
\hline first quartile & $65.1 \%$ & $4.9 \%$ & & $26.3 \%$ & $10.0 \%$ \\
\hline greater than first quartile & $65.8 \%$ & $4.5 \%$ & 0.26 & $29.3 \%$ & $11.4 \%$ \\
\hline lower than median & $63.8 \%$ & $20.1 \%$ & & $25.2 \%$ & $7.7 \%$ \\
\hline median level or greater & $66.0 \%$ & $21.5 \%$ & 0.45 & $28.0 \%$ & $9.5 \%$ \\
\hline lower two treciles & $63.9 \%$ & $19.9 \%$ & & $23.1 \%$ & $6.8 \%$ \\
\hline top thrid & $67.3 \%$ & $22.9 \%$ & 0.62 & $34.5 \%$ & $12.7 \%$ \\
\hline lower nine deciles & $64.6 \%$ & $20.2 \%$ & & $23.9 \%$ & $7.0 \%$ \\
\hline top decile & $66.4 \%$ & $23.5 \%$ & 0.28 & $38.1 \%$ & $15.9 \%$ \\
\hline
\end{tabular}

$\mathrm{T}$-test that mean self assement differs from mean test score in top wealth decile $-2.90$ 
Table 3. Summary of main regression findings

\begin{tabular}{|c|c|c|c|}
\hline & full score & out of 10 & assessment \\
\hline Summary of main specifications: & $(\mathrm{T} 4, \mathrm{c} 4)$ & $(\mathrm{T} 5, \mathrm{c} 4)$ & $(\mathrm{T} 6, \mathrm{c} 4)$ \\
\hline $\begin{array}{l}\text { female } \\
\quad \text { (binary }\{0,1\})\end{array}$ & $\begin{array}{c}-0.0618^{* * *} \\
(0.0213)\end{array}$ & $\begin{array}{c}-0.0438^{* *} \\
(0.0213)\end{array}$ & $\begin{array}{c}-0.0876 * * * \\
(0.0273)\end{array}$ \\
\hline $\begin{array}{l}\text { nonwhite } \\
\quad \text { (binary }\{0,1\})\end{array}$ & $\begin{array}{c}-0.133 * * * \\
(0.0284)\end{array}$ & $\begin{array}{l}-0.151^{* * *} \\
(0.0282)\end{array}$ & $\begin{array}{l}0.131^{* * *} \\
(0.0376)\end{array}$ \\
\hline education & & & \\
\hline $\begin{array}{l}\text { less than bachelors degree } \\
\text { (binary }\{0,1\} \text { ) }\end{array}$ & $\begin{array}{c}-0.0896^{* * * *} \\
(0.0245)\end{array}$ & $\begin{array}{c}-0.0835 * * * \\
(0.0244) \\
\end{array}$ & $\begin{array}{c}0.0276 \\
(0.0323) \\
\end{array}$ \\
\hline $\begin{array}{l}\text { economics - proficiency } \\
\text { (self report }\{0,7\} \text { ) }\end{array}$ & $\begin{array}{l}-0.00768 \\
(0.00664)\end{array}$ & $\begin{array}{l}-0.00402 \\
(0.00660)\end{array}$ & $\begin{array}{l}-0.00474 \\
(0.00777)\end{array}$ \\
\hline $\begin{array}{l}\text { compound interest - proficiency } \\
(2 \text { questions }\{0,2\})\end{array}$ & - & $\begin{array}{c}0.0843^{* * *} \\
(0.0162)\end{array}$ & $\begin{array}{l}-0.0203 \\
(0.0220)\end{array}$ \\
\hline $\begin{array}{l}\text { Light-Ahn CRRA measure } \\
\text { \{most risk adverse } 1, \ldots, 4 \text { least }\}\end{array}$ & $\begin{array}{c}-0.0242^{* * * *} \\
(0.00930) \\
\end{array}$ & $\begin{array}{r}-0.0225 * * \\
(0.00924) \\
\end{array}$ & $\begin{array}{l}0.00286 \\
(0.0121) \\
\end{array}$ \\
\hline $\begin{array}{l}\text { assets } \\
\text { (log value) }\end{array}$ & $\begin{array}{l}0.0191 * * \\
(0.00842)\end{array}$ & $\begin{array}{l}0.0152^{*} \\
(0.00838)\end{array}$ & $\begin{array}{l}0.0190^{*} \\
(0.0109)\end{array}$ \\
\hline $\begin{array}{l}\text { IRA ownership } \\
\text { (binary }\{0,1\} \text { ) }\end{array}$ & $\begin{array}{c}0.0202 \\
(0.0250) \\
\end{array}$ & $\begin{array}{l}-0.00145 \\
(0.0249) \\
\end{array}$ & $\begin{array}{r}-0.0264 \\
(0.0322) \\
\end{array}$ \\
\hline $\begin{array}{l}\text { estimated retirement need } \\
\text { (in } \$ 10,000 \text { ) }\end{array}$ & $\begin{array}{c}0.0220 \\
(0.0208)\end{array}$ & $\begin{array}{c}0.0228 \\
(0.0206)\end{array}$ & $\begin{array}{c}0.0282 \\
(0.0268)\end{array}$ \\
\hline $\begin{array}{l}\text { amount thought about retirement } \\
(\{1,4\} 4 \text { least })\end{array}$ & $\begin{array}{r}-0.00134 \\
(0.0117)\end{array}$ & $\begin{array}{l}-0.0104 \\
(0.0116)\end{array}$ & $\begin{array}{c}0.0239 \\
(0.0150)\end{array}$ \\
\hline $\begin{array}{l}\text { attended meetings on retirement } \\
\quad \text { (binary }\{0,1\})\end{array}$ & $\begin{array}{l}-0.00814 \\
(0.0195)\end{array}$ & $\begin{array}{l}-0.0266 \\
(0.0194)\end{array}$ & $\begin{array}{r}-0.0441^{*} \\
(0.0251)\end{array}$ \\
\hline $\begin{array}{l}\text { plan to work part-time in ret } \\
\quad(\text { binary }\{0,1\})\end{array}$ & $\begin{array}{c}0.0227 \\
(0.0218)\end{array}$ & $\begin{array}{l}0.0177 \\
(0.0217)\end{array}$ & $\begin{array}{c}0.0380 \\
(0.0280)\end{array}$ \\
\hline $\begin{array}{l}\text { have a savings plan for retirement } \\
\text { (\{1:yes, } 3 \text { : more or less, } 5: \text { no }\})\end{array}$ & $\begin{array}{c}0.0132 \\
(0.0244)\end{array}$ & $\begin{array}{c}0.0113 \\
(0.0242)\end{array}$ & $\begin{array}{c}0.0430 \\
(0.0312)\end{array}$ \\
\hline $\begin{array}{l}\text { keeping track of spending - freq. } \\
(\{1,4\}: 4 \text { least })\end{array}$ & $\begin{array}{r}-0.00516 \\
(0.0103)\end{array}$ & $\begin{array}{r}-0.00535 \\
(0.0102)\end{array}$ & $\begin{array}{l}-0.0152 \\
(0.0132)\end{array}$ \\
\hline $\begin{array}{l}\text { satisfied with finacial situation } \\
(\{1,5\}: 5 \text { least })\end{array}$ & $\begin{array}{c}-0.00748 \\
(0.0112)\end{array}$ & $\begin{array}{c}-0.00404 \\
(0.0111)\end{array}$ & $\begin{array}{c}-0.0333^{* *} \\
(0.0142)\end{array}$ \\
\hline $\begin{array}{l}\text { planning period } \\
\text { \{the next few months } 1, \ldots, 5 \text { longer than ten years }\}\end{array}$ & $\begin{array}{c}0.00780 \\
(0.00783) \\
\end{array}$ & $\begin{array}{c}0.0121 \\
(0.00777) \\
\end{array}$ & $\begin{array}{l}0.0174 * \\
(0.0101) \\
\end{array}$ \\
\hline Constant & $\begin{array}{c}0.610^{* * * *} \\
(0.128) \\
\end{array}$ & $\begin{array}{c}0.503 * * * \\
(0.128) \\
\end{array}$ & $\begin{array}{c}0.493^{* * *} \\
(0.168) \\
\end{array}$ \\
\hline Observations & 278 & 278 & 278 \\
\hline $\mathrm{r}^{\wedge} 2$ - predicted from $\mathrm{p}$-score & 0.403 & 0.456 & 0.198 \\
\hline
\end{tabular}

Specifications include fixed effects by employer type 
Table 4. Tobit dependent variable: percent score on 12 item financial literacy quiz

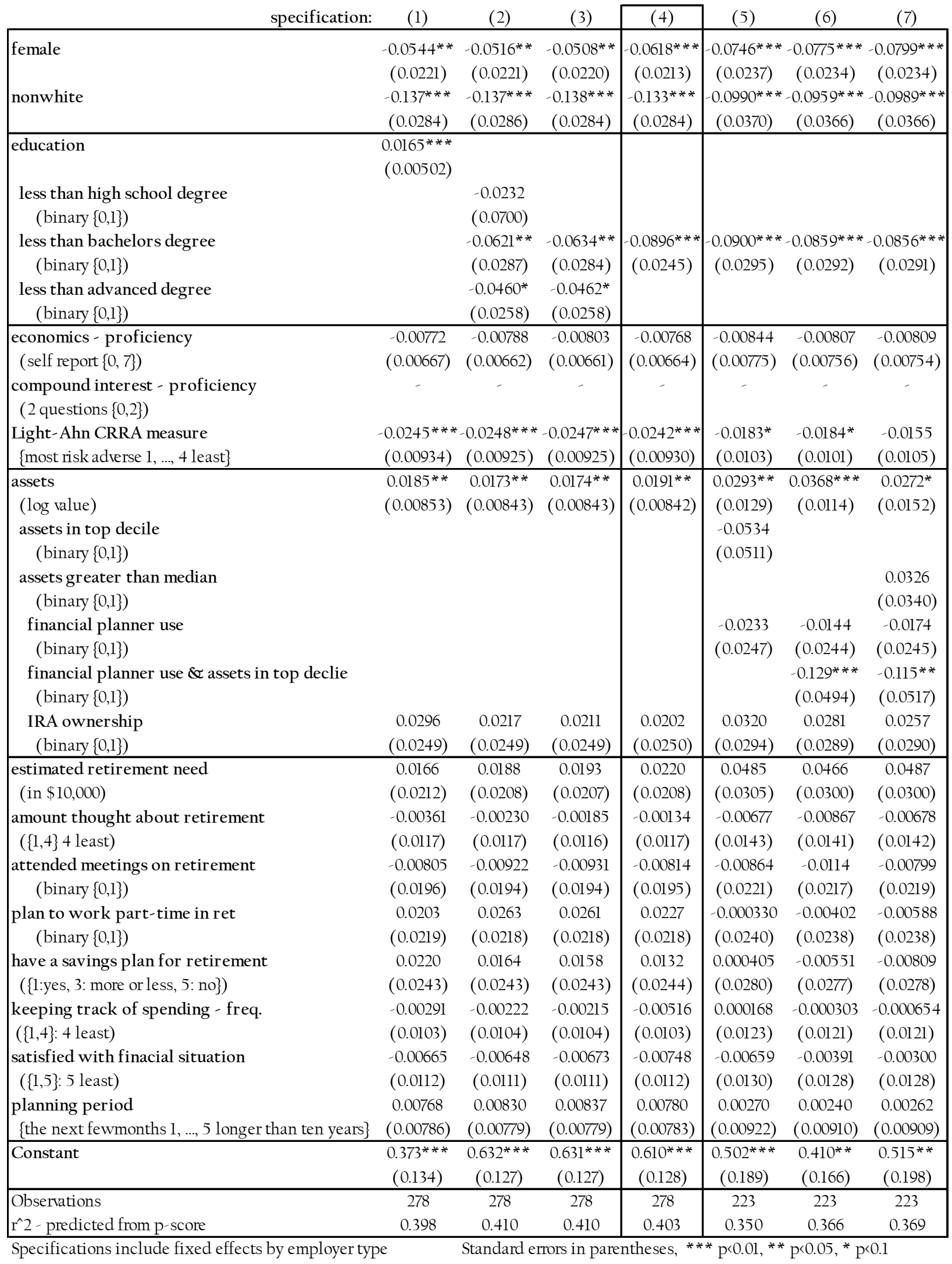


Table 5. Tobit dependent variable: percent score on 10 item financial literacy quiz (compound interest questions excluded)

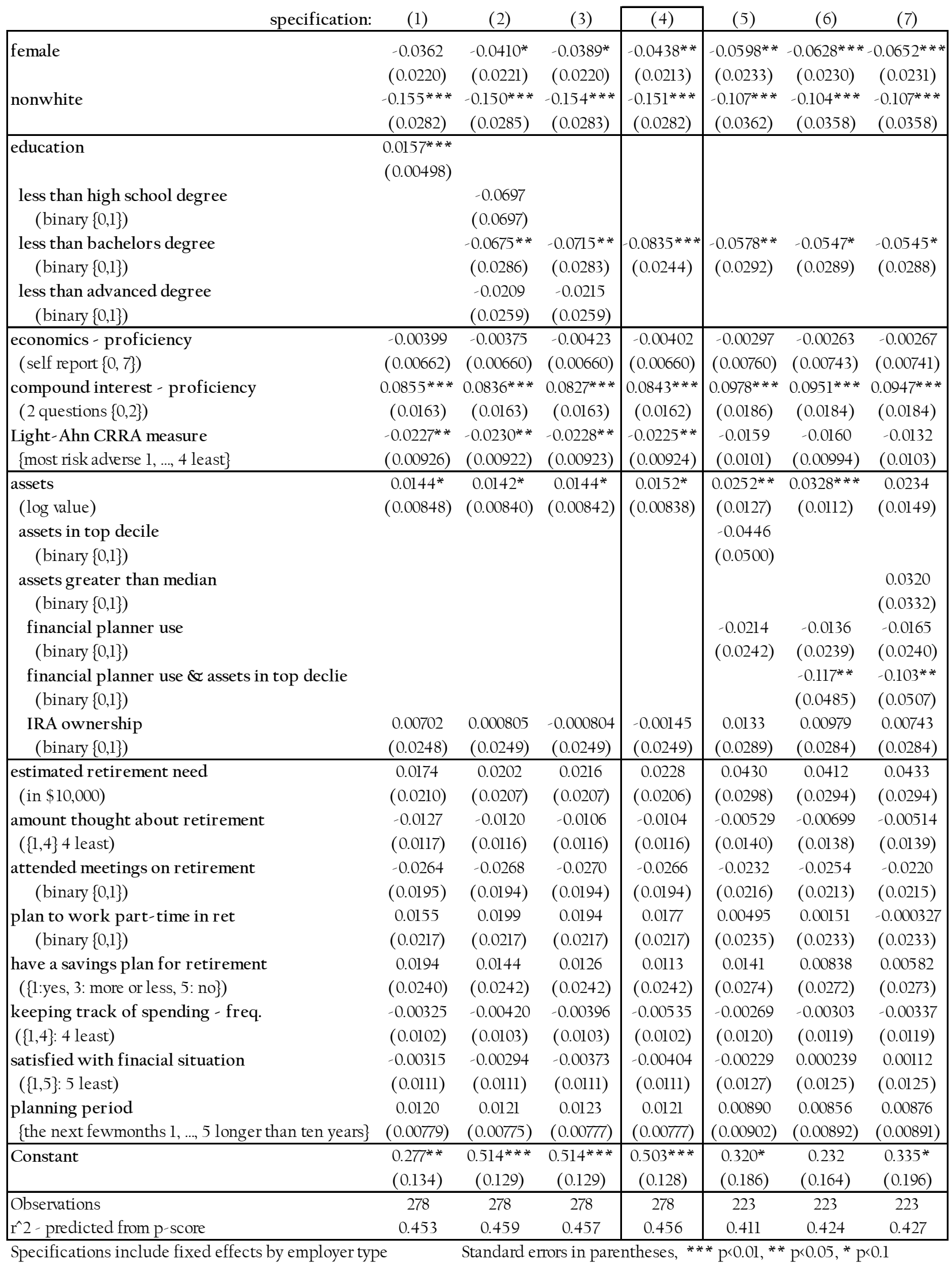


Table 6. Tobit dependent variable: percent self-assessed understanding of economics

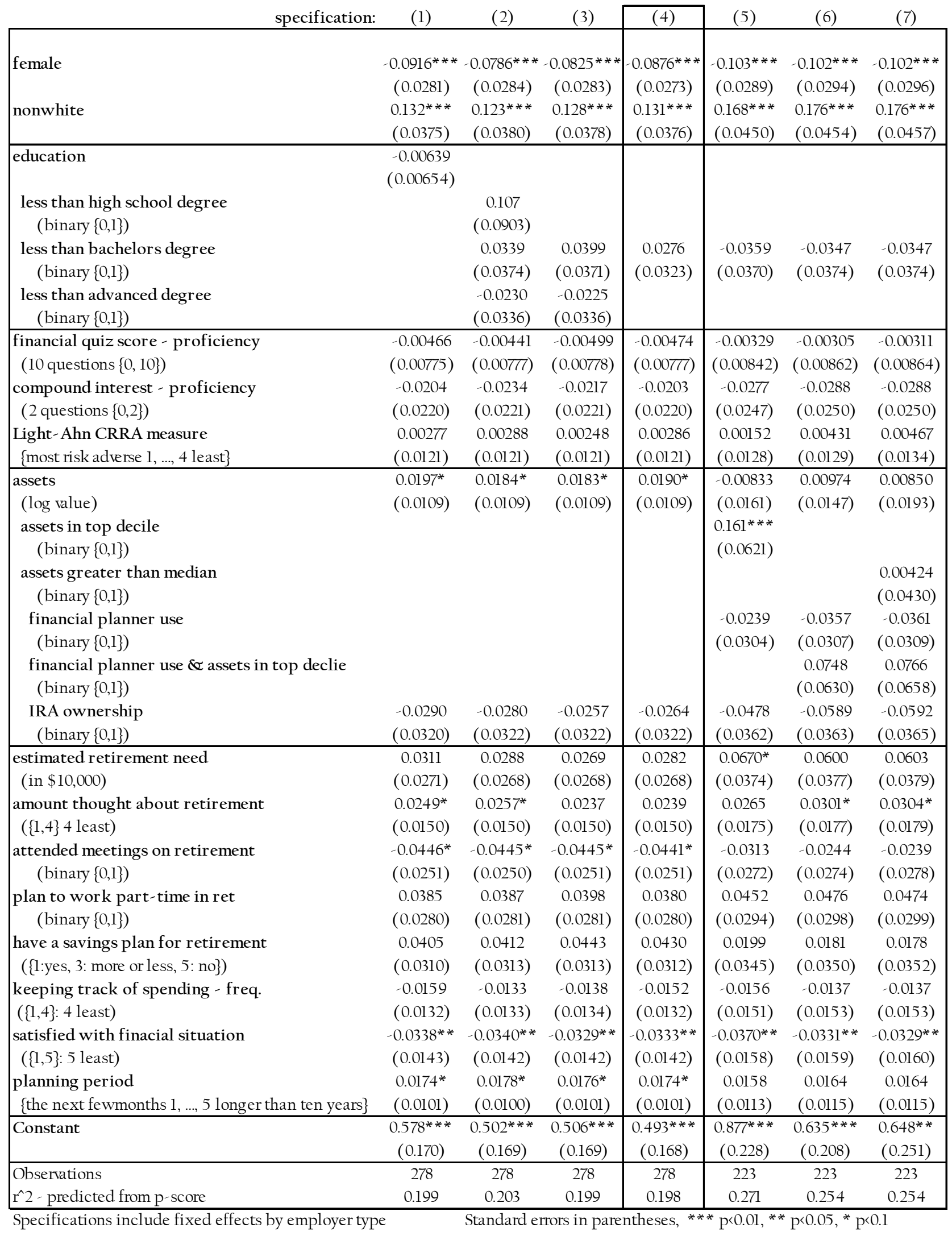



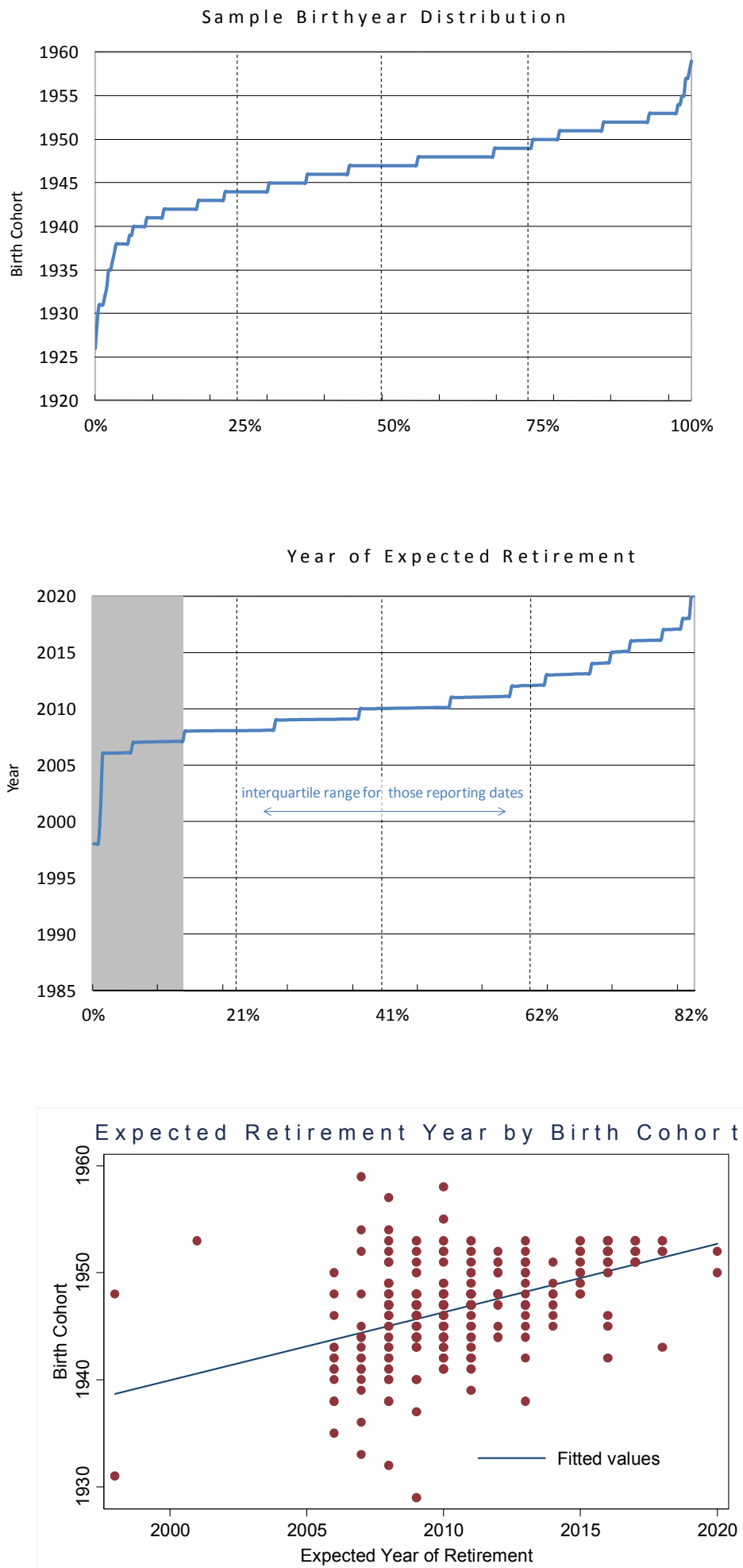

Figure 1. Sample cohort and expected retirement date distribution, as reported 
Panel A:

Reported Assets

(Bottom Three Quartiles)

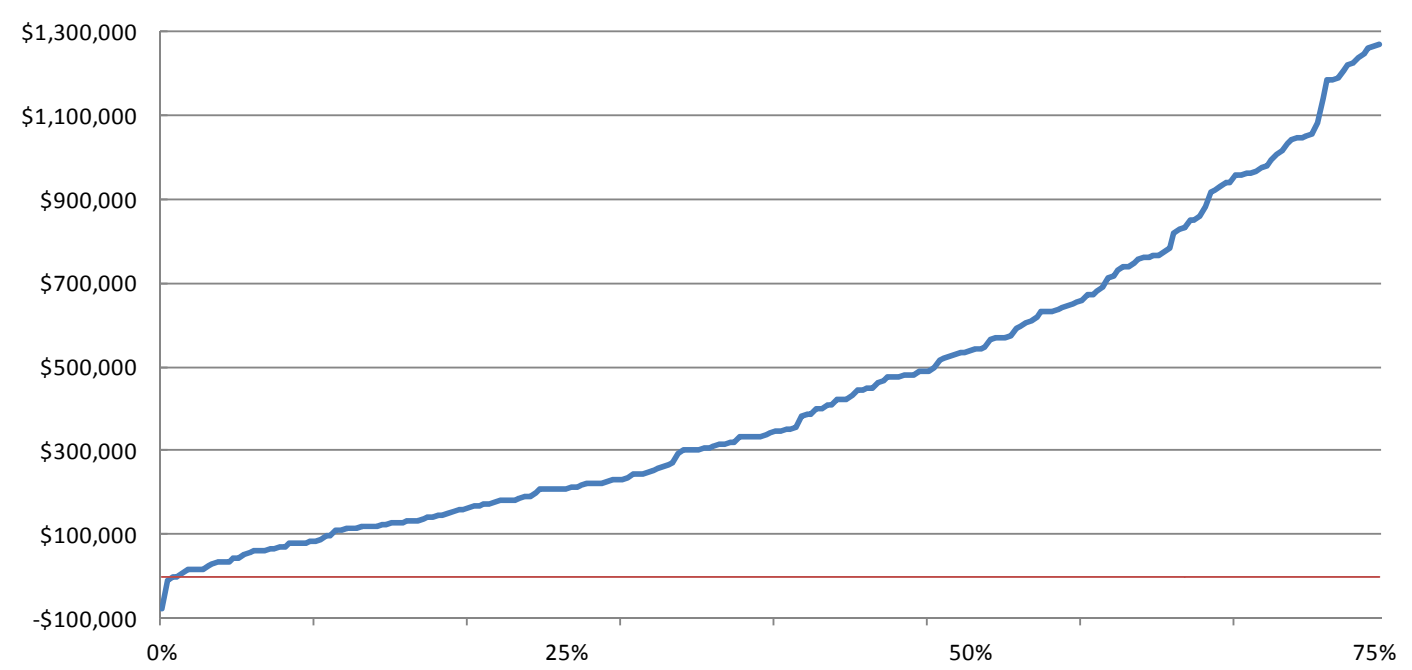

Panel B:

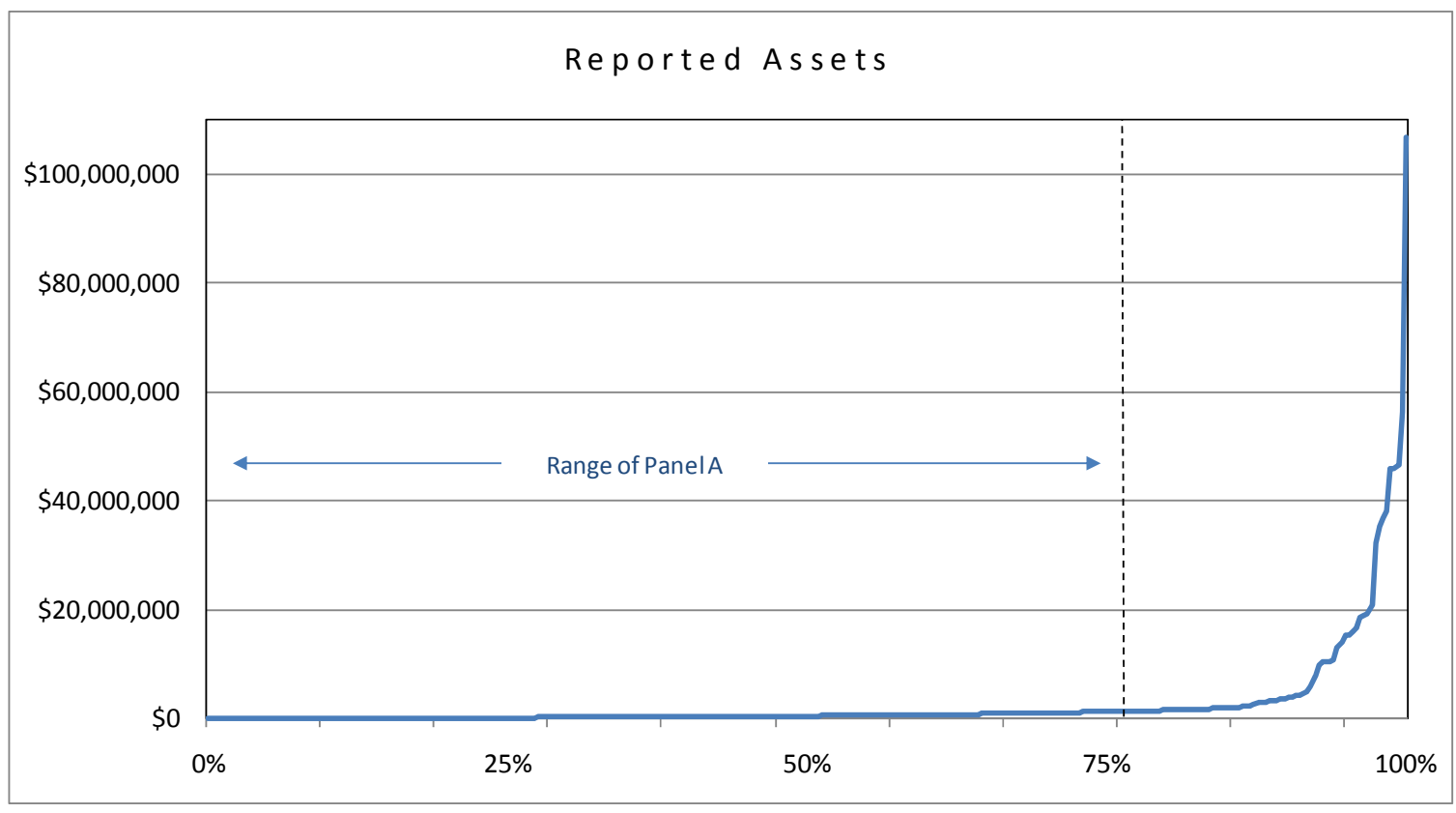

Figure 2. Sample wealth distribution 